\title{
CONFLICT MANAGEMENT (MANAJEMEN KONFLIK) PADA PT. BANK CIMB NIAGA CARD CENTER BINTARO (Studi Kasus Penanganan Konflik Antara Karyawan Ex Bank Lippo Dan Karyawan Ex Bank Niaga Pasca Merger Periode November 2008 - Juli 2018)
}

\author{
EDI MULYANTO \\ Dosen Program Studi Pendidikan Ekonomi Universitas Pamulang \\ *)email: dosen01755@unpam.ac.id
}

\begin{abstract}
ABSTRAK
Munculnya sebuah conflict pada dasarnya dapat disebabkan adanya perbedaan pemahaman yang dilatarbelakangi oleh pengalaman, pendidikan dan juga budaya yang membentuk persepsi dan interpretasi tidak sama antara pihak yang terlibat di dalam conflict tersebut. Namun demikian, conflict bukan berarti tidak baik dan juga bukan berarti baik, ini semua tergantung cara bagaimana mengelola conflict itu sendiri. Apabila conflict itu dikelola dengan baik, conflict akan dapat memberikan hasil yang baik dan begitu pula sebaliknya (Wirawan, 2010:115). Conflict Management (Wirawan, 2010:129) dapat diartikan sebagai sebuah proses terjadinya perbedaan pemahaman para pihak yang terlibat atau pihak ketiga yang membuat perencanaan strategi conflict dan mengendalikannya agar memperoleh solusi terbaik sesuai yang diinginkan. Conflict antara personil yang pernah terjadi pada PT. Bank CIMB Niaga Card Center Bintaro ini dapat dikatagorikan sebagai sebuah conflict yang tidak besar, maksudnya conflict tersebut tidak begitu mengkhawatirkan organisasi di dalam perusahaan. Conflict yang ada lebih disebabkan karena adanya faktor perbedaan pola pikir, etika berkomunikasi dan masih terlihatnya kesan sesama karyawan saling mempertahankan ego dan arogansi masing-masing. Disinilah letak keingintahuan penulis tentang Conflict Management (manajemen konflik) pada PT. Bank CIMB Niaga Card Center Bintaro. Conflict management memiliki dampak kepada anggota organisasi di dalamnya. Cara yang dilakukan PT. Bank CIMB Niaga Card Center Bintaro dalam mengelola conflict yaitu dengan cara berusaha memperkecil potensi sumber terjadinya conflict. Mengingat merger yang terjadi bersumber dari 2 (dua) organisasi tersebut memiliki potensi conflict, maka perlunya diadakan rapat rutin antar divisi di dalamnya agar tercipta sebiah sinergi yang baik sekaligus pula menciptakan keakraban di antara para personil dalam organisasi tersebut.
\end{abstract}

Kata Kunci: Conflict, Conflict Management, Organisasi 


\section{PENDAHULUAN}

Munculnya sebuah conflict dapat disebabkan oleh adanya perbedaan pemahaman yang dilatarbelakangi oleh berbagai pengalaman, pendidikan dan juga budaya yang membentuk persepsi tidak sama di antara pihak yang terlibat di dalam conflict. Sementara pada saat terjadinya kesamaan persepsi dan pemahaman diantara 2 (dua) orang, hal ini dapat dikatakan telah mencapai makna interpersonil yang terbentuk dari berbagai macam latar belakang hidup dan kehidupan yang tidak sama dari masing-masing individu.

Seluruh karyawan harus mengerti benar tentang bagaimana tradisi budaya dalam organisasinya, sebab pengertian itu terkait pada setiap kebijakan, langkah maupun kegiatan yang diambil dan dilaksanakan sesuai dengan tradisi/ budaya yang ada di dalam organisasi tersebut. Behavior individu dalam sebuah kelompok organisasi akan sangat berdampak terhadap jalannya organisasi. Pada kenyataannya tidaklah mudah, jika penggabungan menjadi 1 (satu) wadah organisasi yang sama pada awalnya berasal dari kelompok organisasi yang berbeda satu sama lainnya. Berdasarkan hasil interview peneliti terhadap salah seorang personil di dalam organisasi tersebut, peneliti memperoleh keterangan bahwa telah terjadi conflict antar personil sesudah merger. "Terjadi conflict sesudah merger dan conflict itu muncul dikarenakan berasal dari budaya perusahaan yang berbeda", ucap seorang narasumber di Bank tersebut. Kemudian narasumber tersebut mencoba memberikan ilustrasi dan contoh kepada peneliti bagaimana perbedaan yang terjadi pada saat melayani nasabahnya di counter teller dan bagaimana cara petugas customer service dalam melayani nasabah dan calon nasabahnya di front office. Perbedaan tampak jelas dan tentu hal ini sudah terbentuk dari pengalaman kerja serta budaya dari organisasi yang lama dari masing-masing personil tersebut. Mengelola conflict berarti mengendalikan dan menjaga agar conflict tetap kondusif bagi perkembangan dan kesinambungan 
berjalannya organisasi, sehingga dinamika tersebut pada akhirnya dapat menghasilkan dampak kinerja organisasi yang positif dan menguntungkan organisasi. Munculnya conflict di CIMB Niaga disebabkan oleh adanya perbedaan tradisi/budaya lama pra merger yang masih terbawa serta melekat pada masing-masing personilnya. Namun demikian, conflict bukan berarti tidak baik dan juga bukan berarti baik, ini semua tergantung cara bagaimana mengelola conflict itu sendiri. Apabila conflict itu dikelola dengan baik, conflict akan dapat memberikan hasil yang baik dan begitu pula sebaliknya (Wirawan, 2010:115).

Pada penelitian ini, tujuan penulis adalah ingin mengetahui sejauh mana conflict management yang terjadi di CIMB Niaga Card Center Bintaro pada periode November 2008 - Juli 2018.

\section{B. Kerangka Teori}

1. Organizational Communication (Komunikasi Organisasional) Organizational communication (komunikasi organisasional) merupakan aspek mendasar yang sangat penting di dalam fungsi organisasi. Perlunya koordinasi di internal organisasi adalah agar semua divisi yang ada di dalamnya dapat berjalan sebagaimana mestinya, sehingga tidak akan mengganggu divisi lainnya. Organisasi akan berjalan apabila kegiatan organisasi dilakukan oleh lebih dari 1 (satu) orang untuk mengerjakan dan menyelesaikannya. Oleh sebab itu setiap anggota organisasi yang terlibat interaksi untuk saling bekerja sama demi tercapainya tujuan organisasinya. Interaksi dalam berkomunikasi pada sebuah organisasi bertujuan agar pesan informasi tersebut betul-betul sampai dan up to date (tepat waktu) kepada personil yang ahli sesuai bidangnya untuk meningkatkan kinerja organisasi. Organizational communication (komunikasi organisasional) menggambarkan behavior atau perilaku organisasi yang terjadi serta bagaimana perilaku mereka yang terlibat di dalamnya pada proses itu berinteraksi dan pada akhirnya mampu menghasilkan makna 
terhadap apa yang terjadi (Pace dan Faules, 1998:33). Dikatakan oleh Greenbaunm bahwa yang termasuk di dalam komunikasi organisasional yaitu arus komunikasi informal dan formal organisasi (Muhammad, 2009:65-67). Dibedakan juga bahwa komunikasi internal dan ekternal dalam melihat fungsi dari komunikasi terutama sebagai media untuk berkoordinasi antar pribadi untuk mencapai tujuan sebuah organisasi dan juga masalah bagaimana untuk mewujudkan dalam bentuk aktivitas yang nyata/riil. Peranan komunikasi semata-mata tidak hanya menyampaikan pesan kepada penerima pesan, tetapi juga akan membentuk behavior organisasionalnya yang pada akhirnya semua personil yang terlibat di dalamnya mengerti apa yang menjadi wewenang dan tanggungjawabnya masing-masing di dalam organisasi tersebut. Dalam sebuah organisasi terdiri dari beberapa kumpulan atau kelompok yang saling berinteraksi satu sama lainnya, namun demikian memiliki tujuan utama pada organisasi tersebut. Yang dimaksudkan komunikasi kelompok yaitu studi tentang bagaimana segala sesuatu yang terjadi pada saat masing-masing orang berinteraksi satu sama lainnya di dalam sebuah kelompok kecil serta bukanlah keterangan tentang bagaimana itu seharusnya sebuah komunikasi dapat terjadi, bukanlah pula tentang nasehat bagaimana caracara yang seharusnya ditempuh (Alvin, 2006:8).

Jika orang-orang yang berada dalam kelompok itu jumlahnya tidak banyak atau relatif sedikit (small group communication), disebut sebagi micro group. Small group communication adalah kelompok yang dalam kondisi tertentu dalam sebuah diskusi masingmasing individu memiliki kesempatan yang sama untuk saling berdialog dan memberikan tanggapan satu sama lainnya. Sebaliknya, jika orang-orang yang berada dalam kelompok itu jumlahnya banyak (large group communication), disebut macro group. Dalam kelompok ini situasi dialogis antar individu sangat jarang terjadi dan lebih sulit dilaksanakan, karena mengingat banyaknya peserta di 
dalamnya seperti contoh adalah dalam kegiatan kampanye.

\section{Organizational Values}

Values (nilai-nilai) sebagai pedoman bagi seseorang untuk bertindak di lingkungan organisasinya tampak terlihat pada saat terjadinya komunikasi individu diantara satu sama lainnya. Jika komunikasi antar individu yang terjadi berbeda latar belakang budayanya dan disatukan, maka hal ini akan membentuk suatu kultur bekerja yang baru. Proses terjadinya penyesuaian terhadap kultur kerja yang baru akan berpotensi munculnya conflict diantara mereka. Organizational Values (Nilai-nilai Organisasi) merupakan aktivitas yang dilakukan dalam organisasi itu dan terlihat nyata/riil dan diyakini sebagai pedoman dan dilaksanakan oleh para individu dalam organisasi.

\section{Conflict and Conflict}

\section{Management}

Conflict adalah salah satu inti dalam kehidupan serta perkembangan manusia yang mempunyai karakteristik yang berbeda-beda. Manusia yang berbeda-beda latar belakang pendidikan, pengalaman hidup dan budayanya menyebabkan timbulnya potensi conflict. Maka hal itu sulit dihindari dan bisa menghambat tujuan organisasi.

Conflict Management (Wirawan, 2010:129) dapat diartikan sebagai sebuah proses terjadinya perbedaan pemahaman para pihak atau pihak ketiga yang membuat strategi conflict dan mengendalikannya agar memperoleh solusi yang diinginkan. Conflict Management dapat dilakukan oleh para pihak yang sedang terlibat di dalam conflict itu sendiri ataupun juga apabila tidak menemui titik terang penyelesaiannya dapat dilakukan melalui cara mediasi dengan pihak ke tiga untuk menyelesaikannya. Conflict Management merupakan cara atau strategi bagaimana mengelola dan mengendalikan serta mengubah conflict menjadi energi positif yang menguntungkan bagi organisasi. Oleh karena itu organisasi perlu mempelajari terjadinya conflict di dalam organisasi. 
C. Pembahasan

1. Hasil Penelitian

\subsection{Kondisi Sesudah Merger}

Merger dapat berdampak positif dan juga bisa negatif bagi personil yang ada di dalam organisasi. Peleburan 2 (dua) institusi ini sama artinya dengan menggabungkan nilai dan budaya yang berbeda menjadi 1 (satu) wadah organisasi. Peleburan 2 (dua) organisasi ini harus disesuaikan agar dapat memperkecil terjadinya perbedaan yang ada di dalamnya. Penyesuaian diri bagi setiap individu sangat penting ketika organisasi sesudah dilakukan merger menjadi sebuah organisasi yang baru dengan melibatkan personil yang sama. Kendati demikian untuk mulai melakukan penyesuaian, organisasi perlu mendukung terciptanya programprogram restrukturisasi kerja. Diluar budaya, perbedaan itu terlihat dalam sistem kerja atas dasar visi dan misi pada perusahaan yang baru. Di CIMB Niaga telah membuat sebuah program/sistem kerja atas penggabungan 2 (dua) organisasi yang berbeda menjadi sebuah sistem kerja yang baru dengan tanpa mengesampingkan satu sama lainnya.

\subsection{Permasalahan Sesudah Merger}

Munculnya problematika baru pasca merger ini hanya bersifat kompetisi antar personil agar dapat mencapai level karir yang lebih tinggi lagi sesuai yang diinginkan oleh masing-masing individu. Sebenarnya permasalahan tersebut tidak ada hubungannya dengan kegiatan merger itu sendiri. Karena hal ini juga terjadi pada saat sebelum dilakukannya merger pada masing-masing karyawan pada organisasi sebelumnya. Pada permulaan dilakukakannya merger, masih tampak adanya arogansi dan ego pada sistem kerja yang baru.

\subsection{Conflict Pada PT. Bank CIMB Niaga Card Center Bintaro \\ Selain perbedaan budaya,} munculnya conflict disebabkan adanya perbedaan behavior value (nilai perilaku) dari masing-masing individu yang menjadi patokan. Value (nilai) menjadi pedoman perilaku bagi 
personil dalam bertindak di lingkungan organisasinya sehari-hari. Apabila setiap personil di dalam perusahaan dapat menjalankan tugas yang sesuai dengan yang dianggap penting, maka sekalipun pekerjaan itu sebenarnya sulit tetapi mereka akan memiliki motivasi dan keinginan yang tinggi dengan segenap energi yang mereka miliki berusaha untuk dapat mencapai tujuan. Nilai kepribadian dan nilai kerja dapat menjadi sebuah sumber daya yang hebat bagi sebuah organisasi. Sebaliknya, jika nilai itu tidak jelas dan bahkan jika mereka tidak mengetahuinya, dampaknya dapat menimbulkan conflict yang akan menghambat kinerja para karyawan di dalamnya. Masing-masing karyawan di dalamnya baik itu ex karyawan Bank Niaga maupun Bank Lippo mempunyai latar belakang sistem bekerja yang berbeda-beda. Pada saat 2 (dua) organisasi tersebut melebur menjadi 1 (satu) organisasi baru, personil yang mempunyai budaya dalam bekerja yang berbeda, mereka akan bekerjasama memahami budaya kerja karyawan satu sama lainnya.
Dari sinilah potensi timbulnya conflict dalam oraganisasi perusahaan. Berdasarkan sumber yang dipercaya, permasalahan itu terjadi pada level strukturalnya. Namun tidak dipungkiri juga menurutnya bahwa munculnya conflict individu dalam perusahaan tersebut. Conflict itu tentu saja wajar bisa terjadi mengingat masih adanya masing-masing ego dan karakter yang berbeda-beda setiap manusia. Hal inilah faktor penyebab terjadinya sebuah conflict, baik yang bersifat individu mapun pada level struktural.

\subsection{The Role of Organizational} Values in Conflict Management (Peran Nilai-Nilai Organisasi di dalam Manajemen Konflik)

Setelah merger dilakukan, maka semua karyawan CIMB Niaga berusaha untuk menjalankan budaya baru dengan kinerja maksimal dan dituntut untuk dapat memiliki performa serta integritas yang tinggi terhadap perusahaan. Hal ini membuat karyawan memiliki kepedulian pada apa yang menjadi visi dan misi dalam 
perusahaan. Misi merupakan pernyataan tertulis yang mencerminkan kegunaan dari perusahaan itu. Visi maupun misi tidaklah lengkap mengingat hanya memberikan penjelasan pada fokus di eksternal utamanya, sehingga diperlukan adanya nilai sebagai landasan dalam bertindak sehariharinya dalam melaksanakan pekerjaan. Dengan demikian selain adanya visi maupun misi perusahaan, para personil perlu menentukan agar bagaimana para personil dapat bekerjasama. Personil bekerja dengan alasan yang berbeda mereka menginginkan hasil yang juga berbeda. Tujuan yang berbeda dapat menimbulkan terjadinya conflict dalam organisasi sebuah perusahaan. Terjadinya sebuah conflict diperlukan conflict management (manajemen konflik) dengan tujuan dapat dibuat strategi penanganannya agar dapat dikendalikan dengan baik supaya menghasilkan yang baik pula

Conflict yang terjadi harus diidentifikasi dan ditemukan penyebabnya, sehingga diketahui faktor apa yang menjadi resources (sumber) masalah terjadinya conflict. Jika sudah diketahui penyebabnya, perlunya approach (pendekatan) sesuai nilai yang ada dalam perusahaan itu semestinya berlaku. Dengan demikian maka akan mudah didapatkan resolusi penyelesaiannya dalam conflict management dalam organisasi perusahaan tersebut

\section{Data analysis (Analisis Data)}

Conflict management yang ada di CIMB Niaga Card Center Bintaro dilakukan dengan cara memperkecil risiko timbulnya conflict. Peleburan 2 (dua) organisasi yang mempunyai perbedaan latar belakang budaya menjadi 1 (satu) organisasi baru yang menyebabkan terjadinya perubahan cara berpikir dan komunikasi mempunyai risiko munculnya conflict. Cara yang ditempuh CIMB Niaga Card Center Bintaro adalah perlunya diadakan rapat rutin supaya terjadi sinergi dan keakraban antara karyawan yang ada. Esensi nilai yang ada dalam rapat tersebut adalah bermusyawarah 
dan bermufakat. Cara lain yang juga diterapkan adalah diadakannya kegiatan seperti outbond yang di dalamnya terdapat unsur kerjasama dan nilai-nilai gotong royong. Akan tetapi jika conflict yang terjadi sudah dirasa mengganggu kinerja perusahaan, maka conflict management telah membentuk apa yang disebut agents of change (agen perubahan) yang beranggotakan sekelompok manajer lini di dalam perusahaan tersebut. Conflict management yang diadakan lainnya yaitu Focus Group Discussion, yang mengakomodir musyawarah untuk mufakat juga, misalnya rapat-rapat rutin yang diselenggarakan agar tercapainya hasil sesuai apa yang menjadi visi dan misi organisasi perusahaan tersebut.

\section{Kesimpulan}

Temuan dalam penelitian ini adalah bahwa merger (penggabungan) dari 2 (dua) perusahaan menjadi 1 (satu) perusahaan tersebut dapat menimbulkan conflict. conflict tersebut terlihat pada mulai awal dilakukannya merger. Oleh sebab itu dipandang perlu adanya conflict management (manajemen konflik) di dalam organisasi PT. CIMB Niaga Card Center Bintaro agar dapat:

1. Memperkecil timbulnya potensi conflict para karyawan dan dapat fokus apa yang menjadi visi dan misi serta tujuan organisasi perusahaan.

2. Perlunya masing-masing karyawan saling menghormati satu sama lainnya dan memahami serta menyadari perbedaan yang terjadi di dalam organisasinya.

Conflict management yang saat ini ditangani hanya jika terjadi conflict besar dan kenyataannya conflict yang terjadi hanya menyangkut persaingan karir, beda pendapat dan antar bagian atau divisi yang tidak ada korelasinya dengan merger. Sehingga penanganannya, conflict management ini diselesaikan antar personil karyawan yang ada atau kepala divisi yang terlibat conflict. Dan itu jarang terjadi mengingat conflict management sudah dilakukan secara rutin pada saat awal dilakukannya merger. Namun 
demikian PT. CIMB Niaga Card Center Bintaro sudah membentuk dan mempunyai team yang mereka namakan agents of change yang bertugas mengontrol potensi timbulnya conflict yang akan muncul sewaktuwaktu. Fungsi dari team yang disebut agents of change ini selalu mengedepankan aspek nilai budaya bermusyawarah dan mufakat sama halnya conflict management yang berupa rapat rutin. Conflict management tersebut mampu menciptakan suasana kerja yang kondusif dan terlihat semakin kompaknya kinerja antar karyawan di dalamnya, yang pada akhirnya sukses mempersatukan perbedaan-perbedaan budaya 2 (dua) bank tersebut.

\section{E. Daftar Pustaka}

'Alvin A.Goldberg dan Carl E. Larson, 2006, Komunikasi Kelompok Proses Diskusi Dan Penerapannya, Jakarta: Universitas Indonesia Press.

'Donald K. Freedheim \& Irving B. Weiner, 2003, Handbook of Psychology: Volume 1, History of Psychology, John Wiley and Sons, Inc., New Jersey
'Eagly, A. H., Johannesen-Schmidt, M. C., and van Engen, M. L, 2003. Transformational, transactional, and laissez-faire leadership styles: A meta-analysis comparing women and men, Psychological Bulletin.

'Kruglanski, A.W., E. Tory Higgins (ed), 2007, Social Psychology : Handbook of Basic Principles, The Guilford Press, New York

'Littlejohn, Stephen W, Theories of Human Communication, Seventh Editions; Relmont California, Wadsworth Publishing Company, 2002

'Muhammad, Arni. 2009, Komunikasi Organisasi, Jakarta: PT. Bumi Aksara.

'Noe, Hollenbeck, Gerhart, Wright, 2000, Human Resource Management:Gaining a Competitive Advantage, International Edition, Third Edition, McGraw-Hill Companies Inc.

'Pace, R Wayne dan Don F. Faules, 1998. Komunikasi Organisasi: Strategi meningkatkan kinerja perusahaan, Bandung: Remaja Rosdakarya.

'Rakhmat, Jalaluddin. "Psikologi Komunikasi" edisi revisi, Remaja Rosdakarya. Bandung, 1998. 
'Reece, B.L and Rhonda Brand, 1993, Effective Human Relations in Organization, Houghton Mifflin Company, Boston-Toronto.

'Wirawan, 2010, Konflik dan Manajemen Konflik : Teori, Aplikasi dan Penelitian, Jakarta: Salemba Humanika. 
